\title{
NEW RECORD OF BRACHYDISTOMUM MICROSCELIS (YAMAGUTI, 1933) (TREMATODA, DICROCOELIIDAE) FROM HOUSE SPARROWPASSER DOMESTICUS BIBLICUS HARTERT, 1904 IN BAGHDAD, IRAQ
}

\author{
Afkar M. Hadi* and Ahlam J. Taher** \\ * Iraq Natural History Research Center and Museum, University of Baghdad, \\ Baghdad, Iraq \\ **Department of Biology, College of Education for Pure Sciences (Ibn Al- \\ Haitham), University of Baghdad, Baghdad, Iraq \\ *Corresponding author: afkar_hadi_iraq@yahoo.com \\ Received Date: 20 October 2019, Accepted Date: 12 January 2020, Published Date: 24 June 2020

\section{ABSTRACT} \\ A total of 30 specimens of house sparrow Passer domesticus biblicus Hartert, 1904 (15 \\ females and 15 males) were collected from gardens of some houses in Baghdad city; all birds \\ were dissected to identify the parasites in vesicle, gizzard, intestine, gall bladder and caecum. \\ One species of trematodes Brachydistomum microscelis (Yamaguti, 1933) was found in the \\ gall bladder and two species of cestodes Anonchotaenia globata (von Linstow, 1879) and \\ Raillietina tetragona (Molin, 1858) were found in the small intestine of house sparrow. \\ Morphologic and morphometric measurements were considered.
}

The genus Brachydistomum Travassos, 1944 is being recorded for the first time in Iraq in the gall bladder of house sparrow, as it was not previously recorded from birds in Iraq.

Keywords: Brachydistomum, Digenia, Gall bladder, House sparrow, Passer, Trematoda.

\section{INTRODUCTION}

Passer domesticus biblicus Hartert, 1904 is a cosmopolitan bird that distributes in the wide world (Taraschewski, 2006). In Iraq, it is an abundance bird, especially in central Iraq (Allouse, 1962; Salim et al., 2006).

Only few previous studies on house sparrow parasites in Iraq were carried out, only two studies about blood parasites were published (Shamsuddin and Mohammad, 1980; Mohammad, 1990). The study of Abdulabas (2005) found that two species of cestodes in the intestine of the house sparrow in Al-Najaf province. Then, Mohammad and Al-Moussawi 
(2012) recorded nematodes in gizzard in Baghdad city. Recently, Jenzeel et al. (2015) and Alsaadi et al. (2016) recorded seven species of cestodes in small intestine of house sparrow in Tikrit city, Iraq.

The aim of the current study is to isolate and identify Brachydistomum microscelis from the gall bladder of house sparrow for the first time in Iraq.

\section{MATERIALS AND METHODS}

A total of 30 specimens of house sparrow (15 females and 15 males) were collected by netting traps from gardens of some houses in Baghdad city Iraq, from March 2018 to July 2019. All birds were dissected to identify the parasites in the biological lab in the College of Education for Pure Sciences (Ibn Al Haitham), University of Baghdad. The parasites were fixed in $70 \%$ ethanol, and then sent to the Iraq Natural History Research Center and Museum for staining and identifying according to Yamaguti (1958) and Bray et al. (2008). All specimens were dyed with the acetocarmine stain and then dealt with ascending concentrations of alcohol passages. Finally, all slides were fixed with Canada balsam following Kinsella and Forrester (1972). All parasites were examined for morphologic and morphometric measurements; examination were performed by digital camera, in addition to the drawing the drawing of the trematode had been done by Lucida camera.

The voucher specimens are stored in Department of Vertebrate- Iraq Natural History Research Center and Museum, University of Baghdad; No. INHM.2019; Trematoda: 1.1.

\section{RESULTS AND DISCUSSION}

Only four of the 30 birds which dissected in the present study (13.33\%), were found infected with two types of parasites, trematodes and cestodes.

The current study revealed that the female of house sparrow was infected with the trematoda Brachydistomum microscelis (two specimens) in the gall bladder and three other birds ( 2 females and one male) were infected with cestodes in the gut Anonchotaenia globata (two specimens) and Raillietina tetragona (three specimens).

The current study revealed a new record of the trematoda Brachydistomum microscelis according to Yamaguti, (1958) and Bray et al. (2008) as follow:

Host Order: Passeriformes

Host Family: Passeridae

Host Genus: Passer

Host Species: domesticus biblicus

Locality: Baghdad, Iraq.

Parasite Group: Trematoda

Parasite Family: Dicrocoeliidae

Parasite Genus: Brachydistomum

Parasite Species: microscelis

Habitat: gall bladder. 
Hadi and Taher

Date of Collecting: 15 April 2019

Specimens Deposited: INHM. 2019: Trematoda, No. 1.1

\section{Taxonomic summary}

The genus Brachydistomum belongs to the family Dicrocoeliidae classified as is based on the Catalogue of Life (2018) as follows:

Kingdom: Animalia

Phylum: Platyhelminthes

Class: Trematoda

Order: Plagiorchiida

Superfamily: Plagiorchioidea

Family: Dicrocoeliidae

Genus: Brachydistomum, Travassos, 1944

Species: microscelis, Yamaguti, 1933

According to the reference Yamaguti (1958) who classified this species as:

Family: Dicrocoeliidae (Odhner, 1911)

Subfamily: Dicrocoeliinae (Looss, 1899)

Tribe: Brachydistomini

Genus: Brachydistomum (Travassos, 1944)

Species: microscelis (Yamaguti, 1933)

\section{Macroscopic description (Based on Brachydistomum microscelis specimens)}

Body lanceolate, its length is approximately 3.3-3.5 millimeters, transparent, tends to be golden color, the anterior end is flexed ventrally and the posterior end is flexed dorsally, taking a distinctive shape, as in Plate (1). 


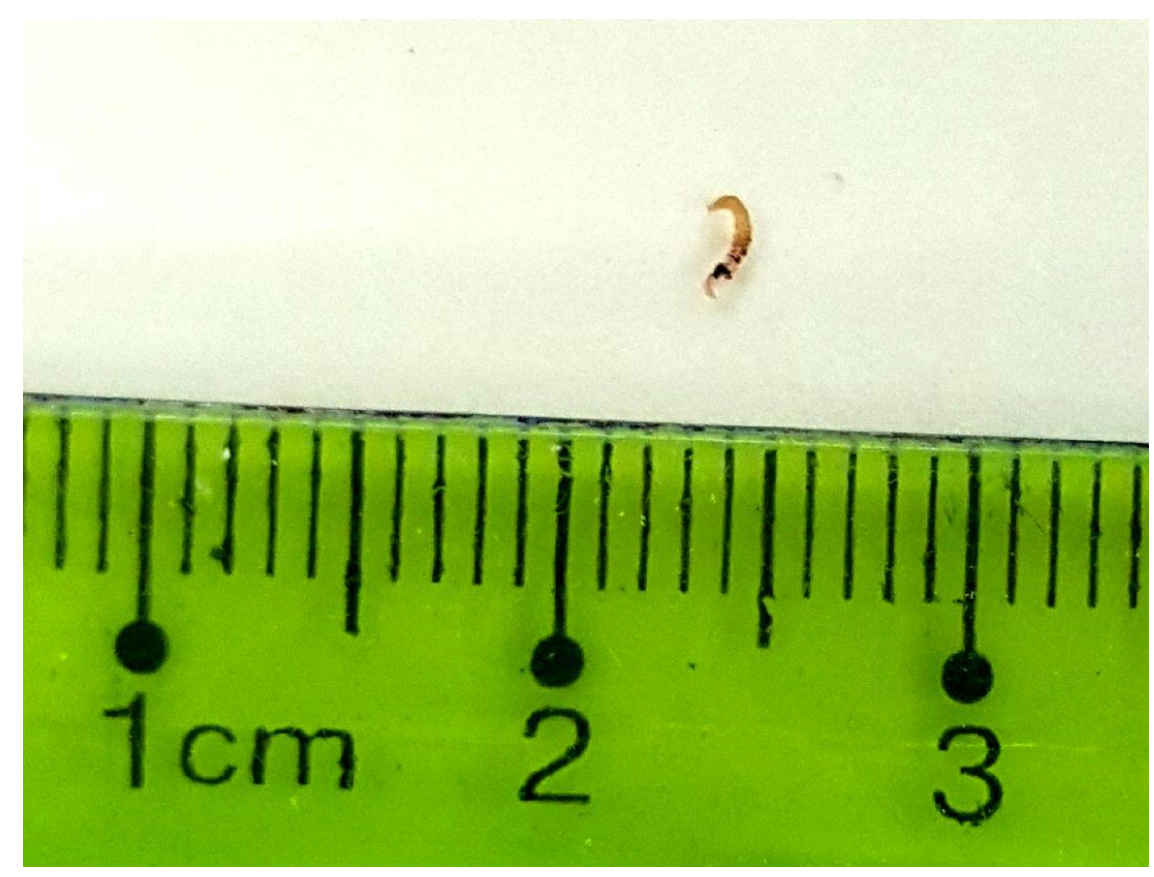

Plate (1): Macroscopic form of B. microscelis from house sparrow in Baghdad, Iraq; by digital camera 12 pixels.

\section{Microscopic description (Based on Brachydistomum microscelis specimens):}

The long body glides narrowly until it is exposed in the ventral sucker that represents the breadth area, curving slightly ventrally, and then the body tapers back to the rounded end. This sharply demarcated the main character for the genus Brachydistomum (Pl.2). Cuticle smooth, oral sucker subterminal, it seems oval wide opening directly into a small globular pharynx, esophagus short, ceca not reaching to the posterior end of the worm. Ventral sucker (Acetabulum) in the anterior half of the body; it is more extensive and broader than the oral sucker (Pl.3).

Testes are nearly round, diagonal or tandem, close to ventral sucker and one another; both of them lay behind of Actabulum area (Pl.4). Ovary submedian, is close to posterior testis. Cirrus pouch is well- developed pre acetabular; genital pore median.

Vitellaria follicles are comparatively broad, composed of few large follicles forming two bands or clusters in the middle third of body (P1.4). Uterus is extensive and much coiled occupying most of hind body and intrudes into fore body that distributed the eggs in most of the body, (Pl.2). Eggs are numerous, oval, of golden color and turned to dark brown when mature. Excretory vesicle is simple, long, tubular, appear under 400x as $\mathrm{Y}$ shape in the posterior end of the body, excretory pore terminal (P1.5). Measurements and drawings of the characteristics are clarified in Table (1) and Figure (1). 
Hadi and Taher

Table (1): Measurements of the main characteristics of Brachydistomum microscelis in house sparrow in Baghdad, Iraq.

\begin{tabular}{|l|l|}
\hline Characteristics & Measurements $(\mathrm{mm})$ \\
\hline Total Body: length & 3.3 \\
Width & 0.45 \\
Oral sucker: length & 0.3 \\
Width & 0.22 \\
Esophagus: length & 0.25 \\
Width & 0.17 \\
Ventral sucker: length & 0.42 \\
Width & 0.25 \\
Testes: length & 0.27 \\
Width & 0.21 \\
Vitellarium follicle: & \\
length & 0.4 \\
Width & 0.42 \\
Excretory vesicle: length & \\
Eggs: length & 0.06 \\
Width & 0.04 \\
& 0.02 \\
\hline
\end{tabular}

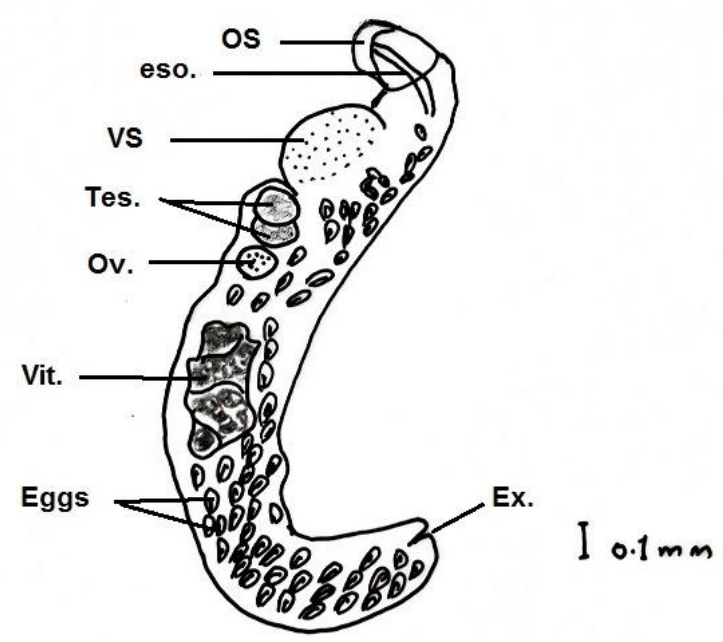

Figure (1): General morphology drawing of B. microscelis from house sparrow in Baghdad, Iraq. (Abbreviations: $\mathrm{OS}=$ oral sucker, eso. $=$ esophagus, $\mathrm{VS}=$ ventral sucker, Tes. = testes, Ov.=ovary, Vit.= vitellarium follicles, Eggs and Ex. = excretory vesicle). 
New record of Brachydistomum microscelis

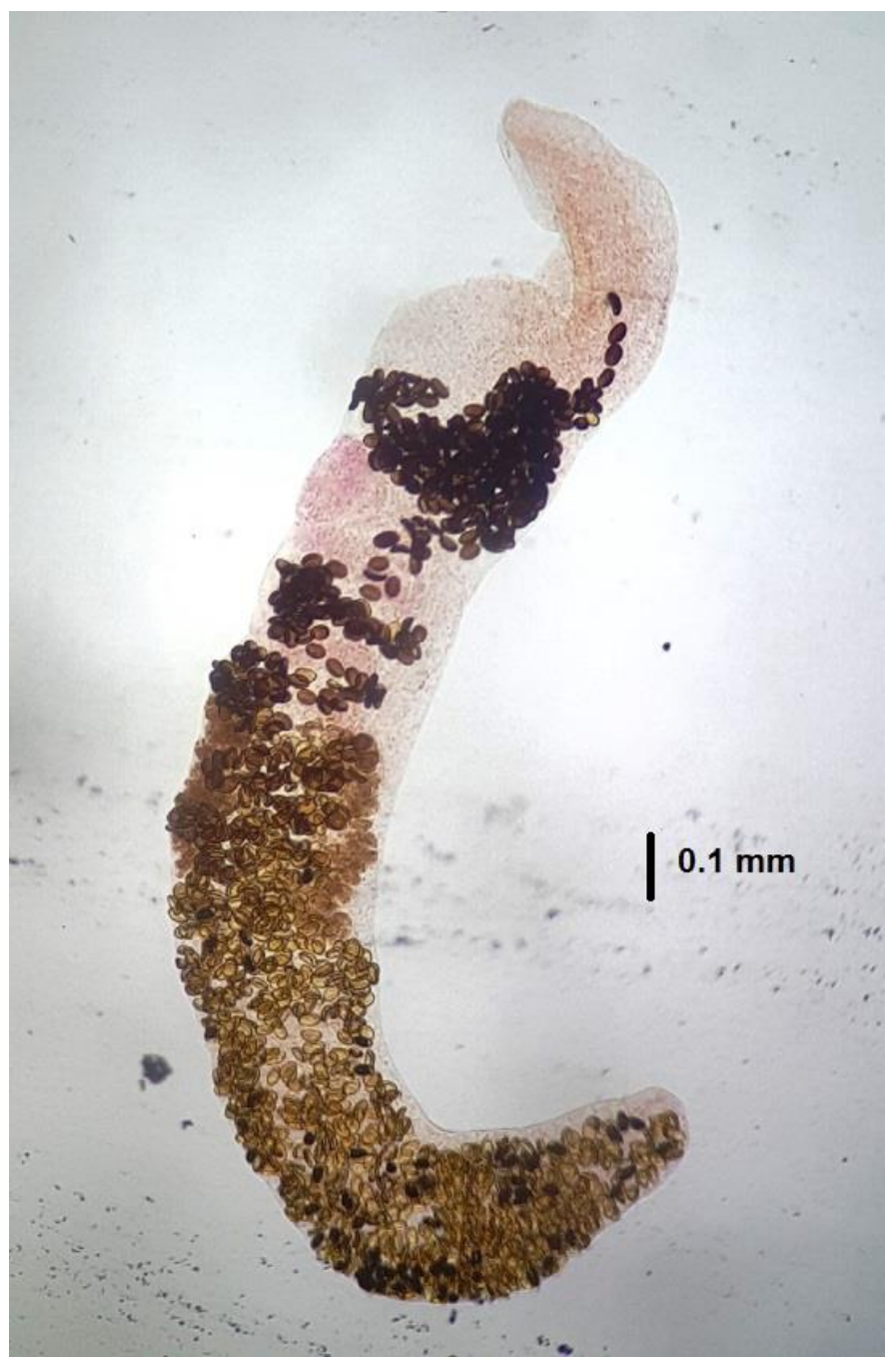

Plate (2): Photograph of B. microscelis from house sparrow in Baghdad, Iraq (40x). 
Hadi and Taher

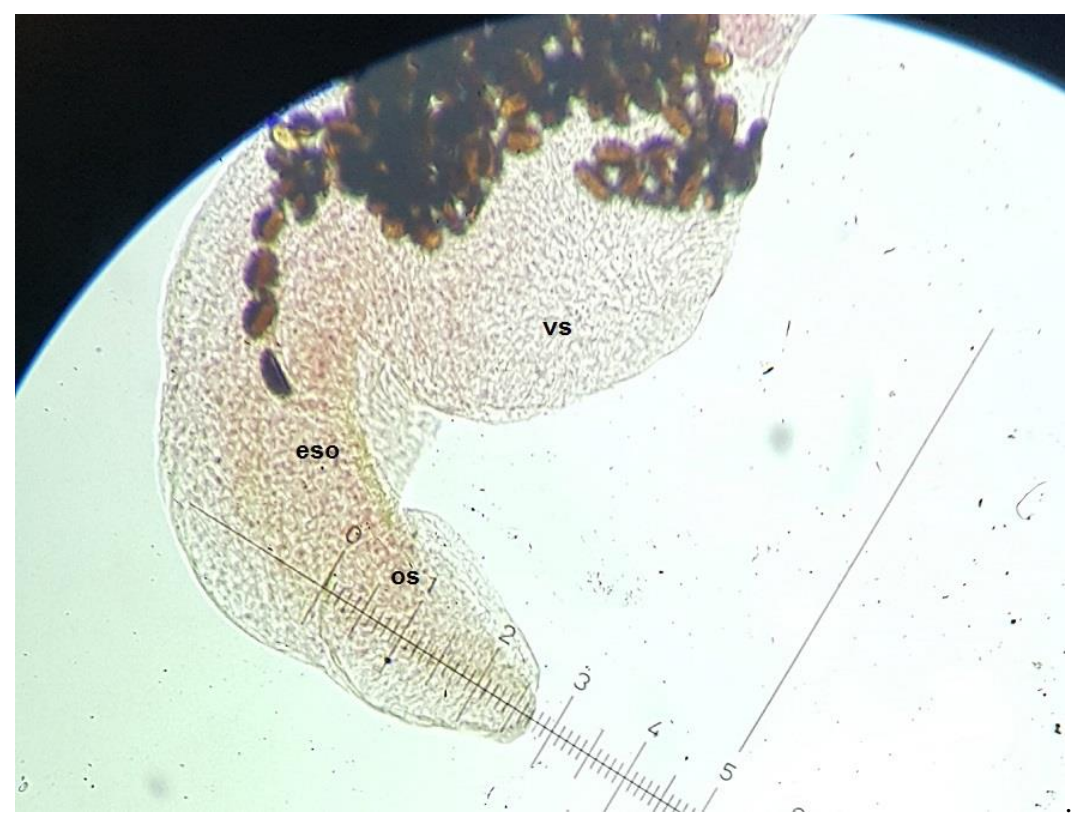

Plate (3): Anterior end of B. microscelis from house sparrow in Baghdad, Iraq (100x). (Abbreviations: os. $=$ oral sucker, eso. $=$ esophagus, vs. $=$ ventral sucker).

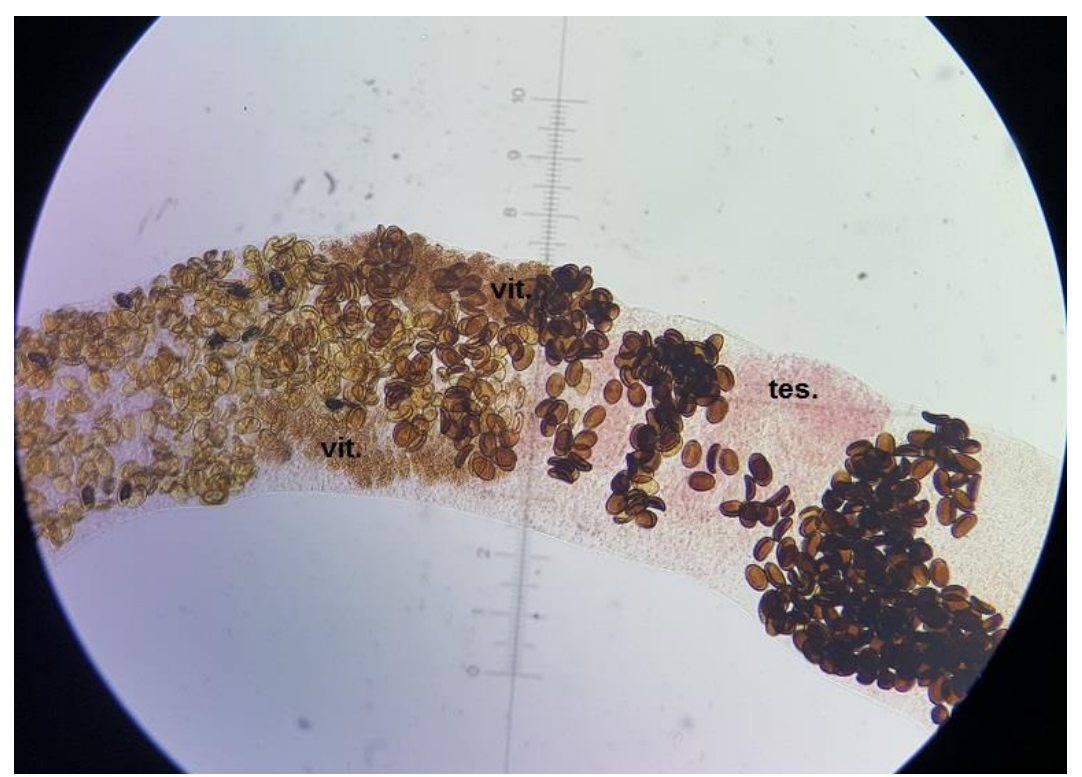

Plate (4): Testes, eggs and vitelline follicles of B. microscelis from house sparrow in Baghdad, Iraq. 100x. (Abbreviations: tes.=testes, vit.= vitellarium follicles). 


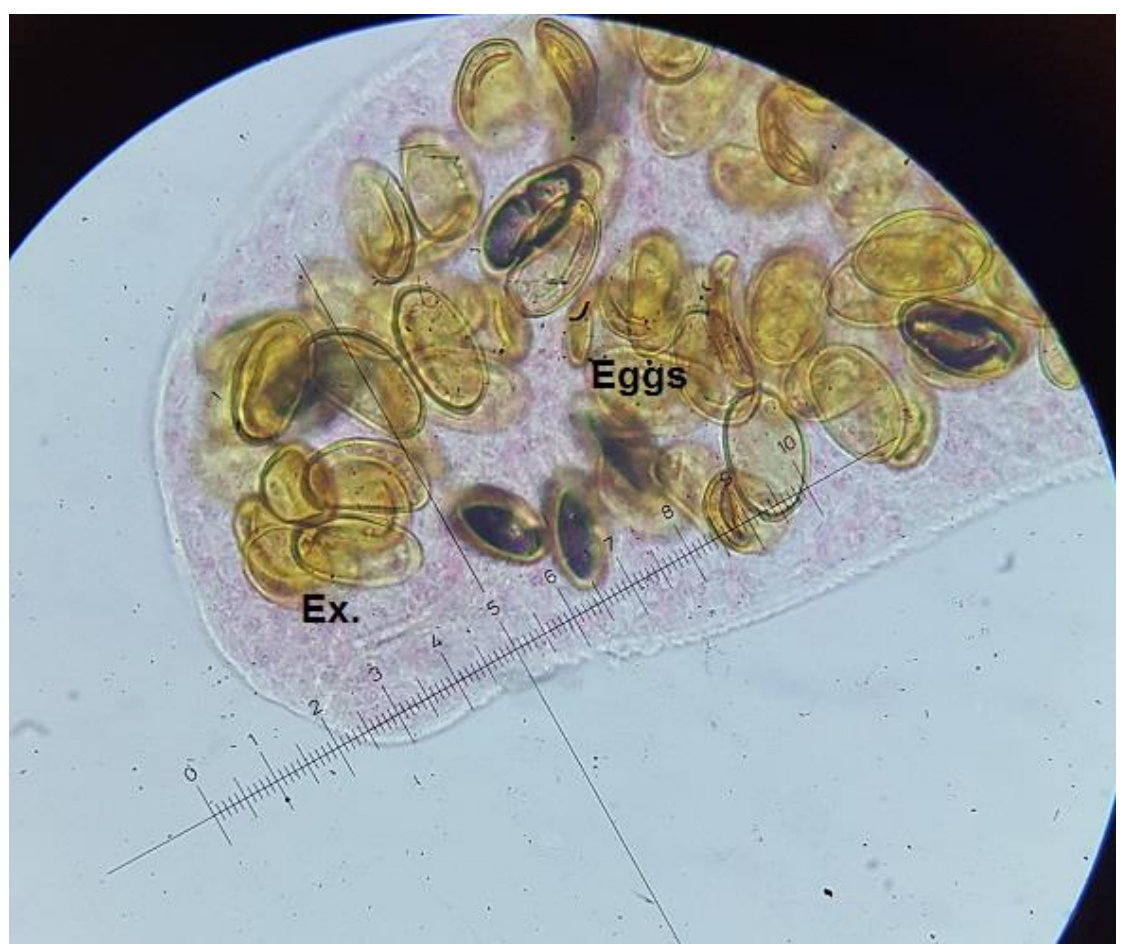

Plate (5): Posterior end of B. microscelis from house sparrow in Baghdad, Iraq (400x). Eggs and excretory vesicle (Ex.).

The results of the current study recorded two cestodes: Anoncotaenia globata and Raillietina tetragona these results were similar to the results of Jenzeel et al. (2015) who recorded A. globata with infection rate $1.2 \%$ and $R$. tetragona with infection rate $36.1 \%$ in house sparrow in Tikrit city, Iraq. Also, previously Mohammad and Al-Moussawi (2013) recorded that the house sparrow in Baghdad was a new host for the cestodes Raillietina echinobothrida with $44.6 \%$ prevalence of infection.

But regarding the recording of the trematode $B$. microscelis in the gall bladder of house sparrow is considered to be the first time in Iraq from all birds. This result is similar to that recorded by Ozmen et al. (2013) who found B. microscelis in the gall bladder of $P$. domesticus in Toros Mountains in Burdur, Turkey. Overall, there were few recordings of the genus Brachydistomum and their species in the world that summarized in Table (2). 
Hadi and Taher

Table (2): Review of references that recording the genus Brachydistomum sp. in birds.

\begin{tabular}{|c|c|c|c|c|c|c|c|c|}
\hline Host order & Host family & $\begin{array}{l}\text { Host } \\
\text { genus }\end{array}$ & Host species & Locality & Parasites genus & $\begin{array}{l}\text { Parasites } \\
\text { species }\end{array}$ & Site & Reference \\
\hline Apodiformes & muscicapidae & Copsychus & saular is & Vietnam & Brachydistomum & longum & Liver & $\begin{array}{l}\text { Oshmarin } \\
(1970)\end{array}$ \\
\hline Apodiformes & Apoclidae & Apus & affinissubfurcatiis & Kasiqui & Brachydistomwm & $a p i$ & $\begin{array}{l}\text { Gall } \\
\text { bladder }\end{array}$ & $\begin{array}{l}\text { Fischthal } \\
\text { and } \\
\text { Robert } \\
(1974)\end{array}$ \\
\hline Passeriformes & Turdidae & Turdus & specious & Cherrapunjee & Brachydistomum & sp. & Intestine & $\begin{array}{l}\text { Soota and } \\
\text { Ghosh } \\
\text { (1977) }\end{array}$ \\
\hline Passeriformes & Corvidae & Corvus & macrorhynchos & $\begin{array}{l}\text { Kagoshima } \\
\text { (Hirakawa } \\
\text { Zoological } \\
\text { Park) }\end{array}$ & Brachydistomum & sp. & $\begin{array}{l}\text { Gall } \\
\text { bladder }\end{array}$ & $\begin{array}{l}\text { Sakamoto } \\
\text { et al. } \\
\text { (1981) }\end{array}$ \\
\hline Passeriformes & Pycnonotidae & Hypsipetes & amaurotis & Shizuoka & Brachydistomum & microscelis & ? & $\begin{array}{l}\text { Uchida } e t \\
\text { al. (1991) }\end{array}$ \\
\hline Passeriformes & Corvidae & Corvus & $\begin{array}{l}\text { macrorhynchos } \\
\text { japonensis }\end{array}$ & Kagoshima & Brachydistomum & sp. & $?$ & $\begin{array}{l}\text { Uchida et } \\
\text { al. (1991) }\end{array}$ \\
\hline Passeriformes & Pycnonotidae & Hypsipetes & amaurotis & Oita & Brachydistomum & microscelis & $\begin{array}{l}\text { small } \\
\text { int. }\end{array}$ & $\begin{array}{l}\text { Kugi } \\
(2004)\end{array}$ \\
\hline Passeriformes & Laniidae & Lanius & collurio & $\begin{array}{l}\text { Záhlinice, } \\
\text { Czech } \\
\text { Republic }\end{array}$ & Brachydistomum & ventricosum & $\begin{array}{l}\text { Gall } \\
\text { bladder }\end{array}$ & $\begin{array}{l}\text { Sitko } \\
\text { (2013) }\end{array}$ \\
\hline Passeriformes & Passeridae & Passer & domesticus & $\begin{array}{l}\text { Toros } \\
\text { Mountains in } \\
\text { Burdur,Turkey }\end{array}$ & Brachydistomum & microscelis & $\begin{array}{l}\text { Gall } \\
\text { bladder }\end{array}$ & $\begin{array}{l}\text { Ozmen et } \\
\text { al. (2013) }\end{array}$ \\
\hline
\end{tabular}

\section{ACKNOWLEDGEMENTS}

Many thanks are due to Mr. Saman R. Afrasiab (retired from Iraq Natural History Researches Center and Museum) for diagnosis of the house sparrow.We would appreciate the efforts of Dr. Furhan T. Mhaisen (Tegnervägen 6B, 64136 Katrineholm, Sweden) and Dr. Atheer H. Ali (Department of Fisheries and Marine Resources, College of Agriculture, University of Basrah) for helping us find the references and trematoda classification keys.

\section{LITERATURE CITED}

Abdulabas, S. K. 2005. Identification study of parasitic fauna on three species of Passeriformes family and its physiological effects in Al-Najaf Al-Ashraf governorate. M.Sc. thesis, College of Science, University of Kufa, 85pp.

Allouse, B. 1962. Birds of Iraq. Vol. 3. Passeriformes. Al Rabitta Press, Baghdad, 288pp. (In Arabic)

Al-saadi, A. A. J., Abdul-Hadi, W. H. and Abdullah, A. H. 2016. Histopathological study of infection with parasitic intestinal helminthes on Passer domesticus in Tikrit city, Iraq. Ibn Al-Haitham Journal for Pure and Applied Sciences, 29: 277-293. (In Arabic)

Bray, R. A., Gibson, D. I. and Jones, A. 2008. Keys to the Trematoda, vol. 3. CAB International. Walling ford, $824 \mathrm{pp}$. 
New record of Brachydistomum microscelis

Catalogue of Life. 2018 edition. Available at: http://www.catalogueoflife.org/col/browse/tree/id/c5821e2a15de304457d1a0f51da5a7 91

Fischthal, J. H. and Robert E. K. 1974.Brachylaimid and dicrocoeliid trematodes of Birds from North Borneo (Malaysia).The Helminthological Society of Washington, Proceedings of the Helminthological Society, 41 (1): 94- 106.

Jenzeel, A. A., Abdullah, A. H. and AL-Hade, W. H. A. 2015. Epidemiology study and identification for intestinal parasites have influence on Passer domesticus in Tikrit City, Iraq. Ibn Al-Haitham Journal for Pure and Applied Sciences, 28 (3): 331- 344.

Kinsella, J. M. and Forrester, D. J.1972. Helminths of the Florida duck, Anas platyrhynchos fulvigula. Proceeding of the Helminthological Society of Washington, 39 (2): 173-176.

Kugi, G. 2004. Studies on the helminth fauna of Vertebrates in Oita Prefecture. Part 3. Mammalian and Avian Helminths, 106 pp.

Mohammad, M. K. 1990. Blood parasites of some Iraqi wild birds. Iraqi Journal Sciences, 31(Supplement): 31-39.

Mohammad, K. M. and Al-Moussawi, A. A. 2012. Gizzard Nematodes of the house sparrow Passer domesticus biblicus Hartert collected in Baghdad city, central Iraq. Bulletin of Iraq natural History Museum, 12 (2): 25-37.

Mohammad, K. M. and Al-Moussawi, A. A. 2013. Raillietina echinobothrida (Megnin, 1881) (Cestoda: Cyclophyllidea) from the house sparrow Passer domesticus biblicus Hartret, 1881 collected in Baghdad city, Central Iraq. Bulletin of Iraq Natural History Museum, 12 (3): 31-36.

Oshmarin, P. G. 1970. Trematodes of domestic and wild birds in the Democratic Republic of Vietnam. In: Oshmarin, P. G., Mamaev, Y. L. and Lebedev, B. I. (eds). Helminths of animals in south-eastern Asia. Nauka, Moscow, p. 5-126. (In Russian)

Ozmen, O., Adanir, R., Haligur, M., Albayrak, T., Kose, O. and Ipek, V. 2013. Parasitologic and pathologic observations of the house sparrow (Passer domesticus). Journal of Zoo and Wildlife Medicine, 44(3): 564-569.

Sakamoto, T., Kono, I., Yasuda, N., Sakoh, T., Kawabata, S. 1981. Studies on parasites of corvus: I. Parasites of Corvus macrorhynchos in Kagoshima district. Bulletin of the Faculty of Agriculture, Kagoshima University, 31: 83-93. 
Hadi and Taher

Salim, M. A., Porter, R., Christensen, S., Schiermacker-Hansen, P., Christensen, C. and AlJboor, S. 2006. Field guide to birds of Iraq. Nature Iraq and Birdlife International. $1^{\text {st }}$ edition, 284 pp. (In Arabic)

Shamsuddin, M. and Mohammad, M. K. 1980. Haematozoa of some Iraq birds with description of two new species, Haemoproteus pterocles and Leucocytozoon nycticoraxi (Protozoa: Haemosporina). Bulletin of the Iraq Natural History Museum, 7(4): 111-154.

Sitko, J. 2013. Redescription of Skrjabinus skrjabini and validity reassessment of selected species of Skrjabinus (Digenea, Dicrocoeliidae). Helminthologia, 50(4): 281 - 286.

Soota, T. D. and Ghosh, R. K. 1977. On some trematodes from Meghalaya. Records of the Zoological Survey of India, 73: 111- 122.

Taraschewski, H. 2006. Hosts and parasites as aliens. Journal of Helminthology, 80 (2): 99128.

Uchida, A., Uchida, K., Itagaki, H. and Kamegai, S. 1991. Checklist of helminth parasites of Japanese birds. Japanese Journal of Parasitology, 40 (1): 7-85.

Yamaguti, S. 1958. Systema Helminthum. Vol. I. Digenetic trematodes of vertebrates. Parts I, II. Interscience Published, New York, London, 1575 pp. 
Bull. Iraq nat. Hist. Mus.

(2020) 16 (1): 27-38.

تسجيل جديد للمخرمة

(Trematoda, Dicrocoeliidae)

Passer domesticus biblicus Hartert, من العصفور المنزلي 1904

$$
\begin{aligned}
& \text { في بغداد، العراق } \\
& \text { |فكار مسلم هادي * و احلام جاسم طاهر } \\
& \text { *مركز بحوث و متحف التأريخ الطبيعي، جامعة بغداد، بغداد، العراق } \\
& \text { ***مهم علوم الحياة، كلية التربية للعلوم الصرفة (ابن الهيثم)، جامعة بغداد، } \\
& \text { بغداد، العراق }
\end{aligned}
$$

تأرتخ الاستلام: 2019/10/20، تأريخ القبول: 2020/01/12، تأرتخ النشر: 2020/06/24

$$
\text { الخلاصة }
$$

جمعت 30 عينة من العصفور المنزلي (15 اناث و 15 ذكور) من حدائق بعض المنازل في مدينة بغداد ؛ تم تشريت الطيور للتعرف على الطفيليات في الحويصلة والقانصية والامعاء

$$
\text { الدقيقة والاعور و كيس المرارة. }
$$

عثر على نوع واحد من المثقوبات Brachydistomum microscelis (Yamaguti,1933) في Anoncohtaenia globata (von Linstow, كيس المرارة و نوعين من الديدان الشريطية Raillietina tetragona (Molin, 1858)وفي الامعاء الدقيقة للعصفورالمنزلي.

اجريت القياسات المظهرية والمورفومترية،حيث سُجلَ جنس Brachydistomum Travassos, 1944 لاول مرة في العراق في المرارة للعصفور المنتلي، اذ لم يسبق تسجيله في الطيور الاخرى في العراق. 